\title{
PENINGKATAN KETERAMPILAN GENERIK SAINS SISWA MELALUI TASK BASED LEARNING PADA LARUTAN BUFFER
}

\author{
Ratih Pitasari, Anni Yunaningsih ${ }^{2}$ \\ ${ }^{1}$ SMA negeri 16 Jl. Mekar Sari no. 82 Bandung Jawa Barat \\ ${ }^{2}$ Fakultas Tarbiyah dan Keguruan UIN Sunan Gunung Djati Bandung \\ Jl. A.H. Nasution No 105 Cibiru Bandung Jawa Barat-Indonesia \\ email:zenabsc@gmail.com
}

\begin{abstract}
ABSTRAK
Task based learning (TBL) adalah suatu pembelajaran yang menuntut siswa berperan aktif dalam kegiatan pembelajaran sehingga diharapkan dapat meningkatkan keterampilan berpikir dalam memahami konsepkonsep yang dipelajari. Keterampilan generik sains memiliki indikator, di antaranya: pengamatan langsung, pengamatan tidak langsung, bahasa simbolik, inferensi logika, pemodelan matematik, dan membangun konsep. Tujuan penelitian ini untuk mendeskripsikan keterampilan generik sains siswa pada pembelajaran TBL larutan buffer. Metode penelitian yang digunakan adalah metode peneitian tindakan kelas dengan dua siklus sesuai ketercapaian KKM. Subjek penelitian adalah siswa kelas XI IPA-5 dari salah satu SMA negeri di kota Bandung sebanyak 32 orang. Instrumen yang digunakan adalah soal yang mengacu pada indikator keterampilan generik sains. Data hasil penelitian diolah dengan menggunakan statistika dekriptif persentase. Hasil tes keterampilan generik sains siswa mengalami peningkatan dengan rata-rata pada siklus I 70 dan siklus ke II 82. Maka hasil peneltian ini menunjukkan bahwa penerapan TBL dalam pembelajaran kimia dapat meningkatkan keterampilan generik sains siswa.
\end{abstract}

Kata Kunci: Task Based Learning (TBL),Keterampilan generik sains, buffer.

\begin{abstract}
Task Based Learning (TBL) is a kind of learning that requires students to actively participate in learning activities that are expected to improve thinking skills in understanding the concepts being studied. Generic science skill has several indicators, i.e. direct observation, indirect observation, symbolic language, logic inference, mathematical modeling, and building concepts. The purpose of this study was to describe generic science skills of students in learning the concepts of buffer solution through TBL. The method used was classroom action research (two cycles) according to the achievement of KKM. The subject of this study was 32 students belong to class XI IPA-5 in a state high school located in Bandung city. The instrument used in this study was questions/problems refers to indicators of generic science skills. The resulting data was processed using descriptive statistical percentages. The generic science skills test results of students has increased with an average of 70 in the first cycle and 82 in the second cycle. Thus, the results of this research indicate that the application of TBL in chemistry learning could increase the generic science skills of students.
\end{abstract}

Keywords: Task Based Learning (TBL), generic science skills, buffer. 


\section{PENDAHULUAN}

Kimia merupakan salah satu cabang dari IPA. IImu kimia mempelajari bangun (struktur) materi, reaksi transformasi materi dalam proses alamiah, melalui eksperimen dilaboratorium yang menghasilkan sebuah teori yang dapat berguna bagi kehidupan $[1,2,3]$. Konsep dalam ilmu kimia berkaitan erat dengan fenomena yang terjadi di alam, oleh karena itu diperlukan suatu kemampuan penalaran yang lebih tinggi agar dapat memahami konsep kimia.

Salah satu konsep kimia adalah larutan penyangga/buffer. Materi larutan bufer terdiri dari beberapa konsep yaitu pengertian larutan bufer, prinsip kerja, kapasitas, perhitungan $\mathrm{pH}$ menggunakan persamaan Handerson-Hasselbalch dan larutan bufer dalam kehidupan sehari-hari [1]

Keberlangsungan pembelajaran kelas XI IPA-5 salas satu SMA Negeri di kota Bandung sudah cukup aktif. Namun keefektifan cara belajar siswa belum sepenuhnya tercapai. Beberapa siswa masih kurang aktif dalam proses pembelajaran sehingga berdampak pada hasil belajar siswa belum optimal mencapai KKM yang telah ditentukan. Kesulitan belajar yang dialami siswa ketika dihadapkan dengan konsep abstrak, seperti konsep larutan bufer mengakibatkan motivasi belajar siswa menurun sehingga hasil belajar dan keterampilan berpikir siswa menjadi rendah.

Diperlukan suatu pembelajaran yang menuntut siswa aktif dan dapat meningkatkan keterampilan berpikir dalam memahami konsep-konsep yang terdapat dalam larutan bufer. Salah satu alternatif adalah menerapkan indikator-indikator seseuai keterampilan generik sains. Keterampilan generik sains merupakan kemampuan berpikir dan kemampuan seseorang untuk bertindak berdasarkan kemampuan sains yang dimilikinya [4].

Berdasarkan hakikat pendidikan kimia, kemampuan generik sains dikategorikan menjadi sembilan indikator, diantaranya yaitu: pengamatan langsung, pengamatan tidak langsung, pemahaman tentang skala, bahasa simbolik, kerangka logika taat asas, inferensi logika, hukum sebab akibat, pemodelan matematik, dan membangun konsep [5].

Sejumlah riset membuktikan, bahwa jika suatu pendekatan pembelajaran yang diberikan oleh guru dapat membuat siswa aktif dalam proses pembelajaran, serta guru menyajikan pembelajaran yang relevan dan menyenangkan maka akan menghasilkan pengalaman belajar yang dapat meningkatkan motivasi siswa untuk belajar sehingga dapat meningkatkan keterampilan siswa [6]. Guru memiliki peran penting untuk menciptakan pembelajaran yang efektif sehingga dapat mencapai tujuan pembelajaran yang diharapkan.

Upaya yang dapat dilakukan untuk meningkatkan hasil belajar siswa, guru harus merancang suatu pembelajaran yang dapat meningkatkan keterampilan generik sains siswa. Salah satu pembelajaran yang dapat meningkatkan kemampuan berpikir siswa adalah task based learning. Task based learning (TBL) adalah suatu pembelajaran yang menuntut siswa untuk berperan aktif dalam kegiatan pembelajaran [7]. Karakteristik dalam pembelajaran ini, siswa harus belajar bekerja sama dengan teman-teman sekelompoknya untuk menyelesaikan suatu masalah, karena setiap anggota kelompok memiliki tugas peran masing-masing.

Hasil penelitian [7] menunjukkan bahwa task based learning ini cocok diterapkan dalam pelajaran kimia yang memerlukan percobaan atau praktikum. Kelebihannya melalui tugas yang diberikan, siswa dapat memilih langsung sumber daya yang tersedia untuk menyelesaikan tugas tersebut. Pembelajaran task based learning dapat memunculkan inisiatif yang ada dalam diri siswa dan mengeksplorasi pengetahuan siswa secara mandiri. Maka dalam pembelajaran ini, siswa dapat mengembangkan keterampilan berpikir yang dimilkinya.

Berdasarkan uraian di atas, peneliti tertarik untuk mengembangkan pembelajaran task based learning tersebut pada konsep larutan penyangga untuk meningkatkan keterampilan generik sains siswa. Penelitian ini berkolaborasi dengan guru kimia di salah satu SMAN di kota Bandung yang membahas mengenai bagaimana upaya peningkatan keterampilan generik sains siswa melalui penerapan task based learning pada konsep larutan bufer.

Merujuk pada permasalahan tersebut maka tujuan yang diharapkan adalah menganalisis kemampuan generik sains siswa pada konsep larutan bufer melalui pembelajaran model TBL.

\section{METODE PENELITIAN}

Metode yang digunakan dalam penelitian ini adalah penelitian tindakan kelas yang didasarkan 
permasalahan yang dialami guru dan keadaan siswa pada saat pembelajaran kimia di kelas. Penelitian tindakan kelas ini terdiri dari empat komponen kegiatan pokok yaitu: (a) Perencanaan (planning); (b) Tindakan (acting); (c) Pengamatan (observing); (d) Refleksi (reflecting). Pada pelaksanaannya, keempat komponen kegiatan pokok itu berlangsung secara terus-menerus atau disebut siklus, hal ini yang menjadikan ciri dari penetian tindakan. Siklus pelaksanaan tindakan kelas dalam PTK dapat dilihat pada Gambar 1.

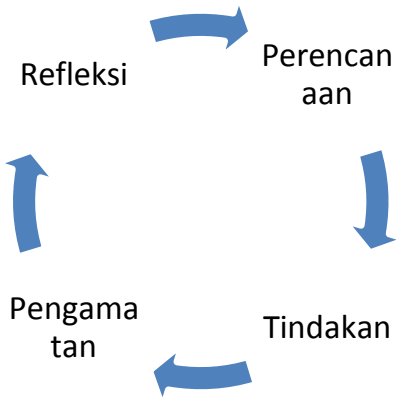

Gambar 1. Penelitian Tindakan Kelas [8]

Pelaksanaan penelitian dilakukan dua siklus sesuai target ketercapaian hasil belajar siswa di atas nilai KKM. Subjek dalam penelitian adalah siswa salah satu SMA Negeri di kota Bandung kelas XI IPA-5 yang berjumlah 32 orang. Penelitian ini dilaksanakan karena siswa mengalami kesulitan saat menghadapi konsep yang memiliki, banyak rumus atau perhitungan seperti pada konsep larutan bufer yang meliputi menjelaskan sifat larutan, menentukan $\mathrm{pH}$, dan peranan larutan penyangga dalam tubuh makhluk hidup. Instrumen yang digunakan berupa lembar kerja dan soal yang mengacu pada indikator KGS.

\section{HASIL DAN PEMBAHASAN}

\section{Pelaksanaan Penelitian Tindakan Kelas Siklus I \\ Perencanaan}

Tim peneliti melakukan diskusi untuk menyusun perencaan pembelajaran yang akan dilaksanakan sesuai dengan permasalahan yang dialami saat pembelajaran sebelumnya. Materi yang dipilih mengenai larutan bufer. Dirancang kegiatan pembelajaran yang sesuai tahapan model TBL dengan indikator-indikator yang mengacu pada keterampilan generik sains. Selain itu juga disusun LKS yang sesuai tahapan TBL.

\section{Pelaksanaan Pembelajaran}

Pelaksanaan pembelajaran dilakukan oleh guru kimia sekolah tersebut. Pembelajaran dilaksanakan sesuai dengan perencanaan yang telah disusun bersama tim. Siswa dikelompokkan dengan anggota masing-masing kelompok 6 orang. Setiap anggota kelompok memiliki tugas masing-masing sebagai perencana, pengumpul informasi, pengorganisir data, pendesain skema, penyiapan percobaan, dan presenter.

Pada tahap pelaksanaan dilakukan observasi oleh observer sebagai tim peneliti. Observasi dilakukan untuk meninjau aktivitas siswa maupun guru ketika proses pembelajaran. Dibuat lembar observasi kegiatan pembelajaran sehingga observer bisa melaksanaan observasi secara akurat.

\section{Tanggapan Observer}

Berdasarkan hasil data dari lembar observasi, observer menyampaikan hasil pengamatannya terhadap pembelajaran task based learning yang telah diterapkan yaitu sebagai berikut:

a) Guru belum dapat menjelaskan tugas yang harus dikerjakan siswa dalam LKS Task Based Learning.

b) Sebagian besar siswa masih kurang aktif dalam diskusi kelompok.

c) Sebagian besar siswa masih kebingungan untuk menyelesaikan setiap tugas dalam LKS Task Based Learning.

d) Guru belum bisa menggunakan waktu dengan baik.

e) Sebagian besar siswa masih sedikit yang menjawab pertanyaan, memberikan pertanyaan dan memberikan gagasan.

f) Guru kurang memberikan bimbingan dan arahan kepada siswa pada saat penyelesaian tugas dalam LKS Task Based Learning.

\section{Refleksi Siklus I}

Berdasarkan beberapa temuan dan hasil observasi yang diperoleh observer pada pembelajaran siklus I, selanjutnya dilakukan refleksi terhadap pelaksanaan pembelajaran siklus I yang akan digunakan sebagai acuan untuk menyusun rencana kegiatan proses pembelajaran dan penekanan pada guru memfasiltasi siswa agar lebih optimal dalam belajar pada siklus II. Hasil refleksi adalah sbb.

a) Guru perlu melatih siswa agar terbiasa berbagi peran dalam kelompok belajar

b) Siswa perlu dibimbing dan dipancing untuk berani mengajukan pertanyaan, menjawab pertanyaan sehingga aktif berpikir dalam belajar

c) Guru perlu membuat perencaan secara matang agar waktu pelaksanaan sesuai dengan alokasi waktu yang telah ditentukan 
d) Guru perlu meningkatkan usaha mengelola kelas sehingga siswa semua aktif belajar.

\section{Siklus II}

\section{Prencanaan}

Perencanaan pembelajaran dibuat sesuai dengan hasil refleksi pada siklus I, Tidak banyak perubahan dalam sistem penyusunannya hanya berbeda pada materi yang di sajikan. Pada siklus II materi yang disampaikannya adalah mengenai $\mathrm{pH}$ buffer.

\section{Pelaksanaan}

Pelaksanaan pembelajaran pada siklus II didasarkan pada masukan hasil refleksi. Guru lebih meningkatkan pada teknik dan pengeloaan pembelajaran agar siswa lebih aktif dan termotivasi dalam belajar. Semua tugas setiap siswa dalam kelompokkan secara umum lebih baik dilaksanakan.

\section{Tanggapan Observer}

a) Siswa sudah mulai aktif dalam berdiskusi dengan kelompok pada setiap tahap pembelajaran task based learning.

b) Siswa sudah mulai mengerti dan menyelesaikan tugas dalam setiap tahap LKS task based learning.

c) Guru selalu membimbing siswa dalam menyelesaikan tugas LKS task based learning.

d) Guru belum dapat menggunakan waktu dengan baik.

\section{Refleksi Siklus II}

Berdasarkan hasil temuan dan observasi yang diperoleh pada pembelajaran siklus II serta hasil observasi dari observer terhadap guru, maka dilakukan refleksi terhadap pelaksanaan pembelajaran siklus II.

a) Guru sudah berhasil mengaktifkan siswa untuk bertanya, menanggapi, dan menyampaikan idenya

b) Guru sudah melakukan pembimbingan selama pembelajaran sehingga siswa antusias mengerjakan LKS

c) Guru masih belum optimal menggunakan waktu yang telah dialokasikan

\section{Keterampilan Generik Sains Siswa setiap Siklus melalui Penerapan Pembelajaran Task Based Learning}

Berikut ini akan dijelaskan analisis data setiap indikator keterampilan generik sains dalam siklus I dan II

1) Membangun Konsep

Dalam indikator ini, siswa diharapkan dapat membangun konsep larutan penyangga yaitu dengan merumuskan masalah, merumuskan hipotesis berdasarkan wacana, mencari informasi mengenai larutan penyangga dari berbagai literatur, dan melaksanakan percobaan berdasarkan rumusan masalah dan hipotesis yang telah dirumuskan.

2) Inferensi Logika

Dari data hasil percobaan siswa dapat menyimpulkan sifat dan prinsip kerja larutan penyangga dalam minuman isotonik serta menyimpulkan cara menentukan $\mathrm{pH}$ larutan penyangga melalui praktikum dan menggunakan perhitungan.

3) Bahasa Simbolik

Pada indikator ini, siswa dapat menuliskan rumus kimia komponen larutan bufer yang terkandung dalam minuman kemasan, dan menuliskan persamaan reaksi larutan bufer ketika ditambah asam dan basa.

4) Pemodelan Matematik

Dalam Indikator ini siswa diharapkan dapat menghitung $\mathrm{pH}$ awal campuran larutan penyangga, menghitung perubahan $\mathrm{pH}$ setelah penambahan asam dan basa, serta siswa dapat membuat grafik berdasarkan data perubahan $\mathrm{pH}$ dalam tabel.

5) Pengamatan Langsung

Dalam Indikator ini siswa dapat mengamati semua reaksi yang terjadi dalam percobaan membuktikan larutan bufer dalam minuman kemasaan dan penentuan $\mathrm{pH}$ melalui perhitungan dengan menggunakan alat indera yang dimiliki, pengamatan yang dihasilkan dapat berupa wujud zat, warna zat, dan bau yang dihasilkan.

6) Pengamatan Tidak Langsung

Pada indikator ini siswa dapat mengamati hasil percobaan larutan bufer dengan menggunakan alat pegukur $\mathrm{pH}$ yaitu indikator universal danpH meter. Siswa diharapkan mampu menggunakan alat tersebut dengan benar.

\section{Keterampilan Generik Sains pada siklus I}

Keterampilan generik sains (KGS) siswa pada pembelajaran task based learning terjadi pada indikator membangun konsep, pemodelan matemati dan bahasa simbolik pada siklus I, diperoleh nilai rata-rata membangun 72 , inferensi logika 65, pemodelan matematika 81 dan bahasa simbolik 82. Data hasil tes keterampilan generik sains pada siklus I dapat dilihat pada Tabel 1 .

Kelompok prestasi sedang pada pemodelan matematik memperoleh nilai tertinggi 90, lebih tinggi dari kelompok prestasi tinggi. Hal ini terjadi karena kelompok prestasi sedang lebih cermat dalam melakukan perhitungan dibandingkan dengan kelompok prestasi tinggi. 
Tabel 1. Data penguasaan keterampilan generik sains pada siklus I

\begin{tabular}{|c|c|c|c|c|c|}
\hline \multirow[b]{2}{*}{ No } & \multirow[b]{2}{*}{$\begin{array}{c}\text { Kelompo } \\
\text { k }\end{array}$} & \multicolumn{4}{|c|}{ \% Penguasaan KGS Siswa } \\
\hline & & $\begin{array}{c}\text { KGS } \\
1\end{array}$ & $\begin{array}{c}\text { KGS } \\
2\end{array}$ & $\begin{array}{c}\text { KGS } \\
3\end{array}$ & $\begin{array}{c}\text { KGS } \\
4\end{array}$ \\
\hline 1 & Tinggi & 89 & 67 & 84 & 83 \\
\hline 2 & Sedang & 60 & 63 & 82 & 90 \\
\hline 3 & Rendah & 67 & 64 & 78 & 72 \\
\hline \multicolumn{2}{|c|}{ Rata-rata } & 72 & 65 & 81 & 82 \\
\hline
\end{tabular}

Keterangan:

KGS 1 = Membangun Konsep

KGS 2 = Inferensi Logika

KGS 3 = Pemodelan Matematik

KGS 4 = Bahasa Simbolik

\section{Keterampilan Generik Sains pada siklus II}

Pada siklus kedua keterampilan generik sains yang diperoleh siswa pada indikator membangun konsep memperoleh rata-rata 93, inferensi logika 62, pemodelan matematik 83 dan bahasa simbolik 100. Kemampuan membangun konsep pada kelompok prestasi rendah melonjak tinggi mencapai 100 , lebih tinggi dari nilai yang dicapai kelompok prestasi sedang yang hanya memperoleh 79. Pembimbingan yang dilakukan guru pada pengisian LKS berdampak pada hasil KGS pada indikator membangun konsep. Tetapi indikator inferensi logika hanya mencapai nilai rata-rata 62 sebagaimana tertera pada tabel 2 .

Tabel 2. Data penguasaan keterampilan generik sains pada siklus II

\begin{tabular}{|c|c|c|c|c|c|}
\hline \multirow{2}{*}{ No } & \multirow{2}{*}{ Kelompok } & \multicolumn{3}{|c|}{$\%$ Penguasaan KGS Siswa } \\
\cline { 3 - 6 } & & KGS & KGS & KGS 3 & KGS \\
\hline 1 & Tinggi & 100 & 72 & 91 & 100 \\
\hline 2 & Sedang & 79 & 59 & 84 & 100 \\
\hline 3 & Rendah & 100 & 56 & 74 & 100 \\
\hline \multicolumn{7}{|c}{ Rata-rata } & 93 & 62 & 83 & 100 \\
\hline
\end{tabular}

Keterangan :

KGS 1 = Membangun Konsep

KGS 2 = Inferensi Logika

KGS 3 = Pemodelan Matematik

KGS 4 = Bahasa Simbolik

Berdasarkan nilai setiap indikator KGS Siklus I dan II, maka diperoleh nilai rata-rata KGS siklus pertama 70 dan siklus II 82. Grafik nilai rata-rata KGS pada silus I dan II dapat dilihat pada Gambar 2.

Peningkatan keterampilan generik sains rata-rata untuk setiap kelompok prestasi menunjukkan bahwa ketiga kategori kelompok tersebut semuanya mempunyai kemampuan yang baik, karena pada setiap siklus nilai masing-masing kelompok tersebut tidak terlalu jauh. Seluruh kelompok belajar lebih berperan aktif dalam semua tahapan TBL. Pada tahap pelaksanaan percobaan siswa aktif,melalui percobaan siswa mampu menemukan sendiri teori yang telah dipelajarinya, selain itu juga dapat melatih siswa cara berpikir ilmiah [9]. Cara belajar TBL menuntut siswa berpartisipasi aktif dengan konsep dan prinsip-prinsip yang diperoleh dari pengalaman dan eksperimen-eksperimen yang mereka temukan sendiri untuk menyelesaikan masalah sehingga akan menghasilkan pengetahuan yang dapat bertahan lama [10].

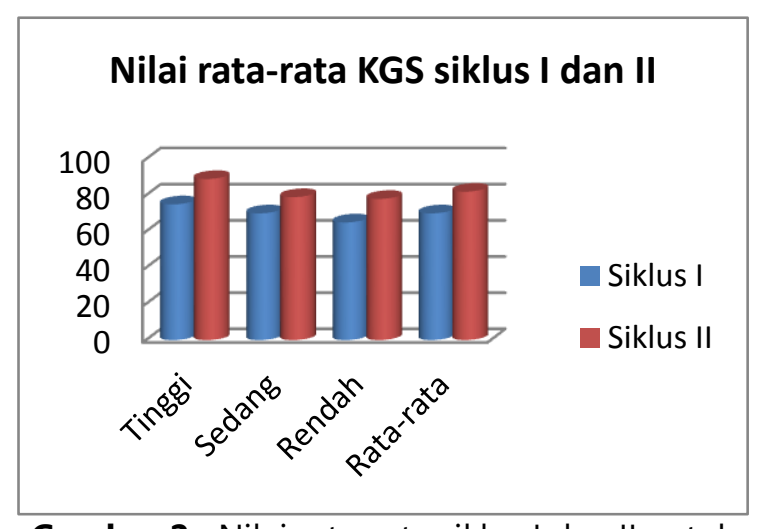

Gambar 2. Nilai rata-rata siklus I dan II untuk setiap kelompok prestasi

Berdasarkan hasil analisis indikator KGS siswa pada pembelajaran task based learning terjadi peningkatan pada indikator setiap siklus. Namun siswa mengalami kesulitan dalam menjawab beberapa soal. Hasil analisis siklus I dan siklus II menunjukkan bahwa indikator menjelaskan terjadinya larutan bufer berdasarkan grafik yang diberikan, kurang baik dibandingkan dengan nilai indikator yang lainnya karena rata-rata kelompok tertinggi, kelompok sedang dan kelompok rendah pada indikator tersebut, dengan hasil kelompok tinggi mampu menjawab soal sebesar 67, kelompok sedang 63, dan kelompok rendah 64 . Keterampilan generik sains yang dikembangkan pada soal tersebut merupakan indikator inferensi logika, yaitu kemampuan siswa menyimpulkan berdasarkan data atau pengetahuan yang telah diperoleh sebelumnya.

Pada kelompok tinggi, sedang maupun rendah diketahui bahwa siswa belum dapat mengerjakan dan menjawab pertanyaan dengan baik. Hal ini disebabkan, sebagian siswa masih kurang memahami atau mengerti mengenai peristiwa terjadinya larutan penyangga berdasarkan grafik atau data dalam tabel. Soal tersebut pada dasarnya,menuntut siswa memahami terlebih 
dahulu unsur-unsur yang membangun prinsip kerja larutan penyangga dengan baik. Hal ini seiring dengan pendapat yang mengatakan bahwa siswa dapat dikatakan memiliki pengetahuan ketika dapat menjelaskan unsur-unsur yang membangun pengetahuan tersebut yang diperoleh dari proses pengalaman yang berulang sehinngga dapat diterima oleh struktur kognitifnya sebagai hasil proses berpikirnya [11] .

Hasil analisis data pada siklus I dan II bahwa nilai tertinggi terdapat soal menuliskan persamaan reaksi ketika larutan bufer ditambah sedikit asam dan sedikit basa. Keterampilan generik sains yang ditingkatkan yaitu bahasa simbolik dengan nilai rata-rata siklus I 82 dan siklus II 100. Hal ini disebabkan siswa yang mengkontruksi belajarnya yaitu dengan menemukan dan mentransformasikan suatu informasi yang kompleks menjadi suatu informasi yang sederhana sehingga akan menghasilkan informasi mudah dipahami oleh dirinya dan menambah pengetahuannya [12].

Berdasarkan hasil tes tertulis yang dilaksanakan pada akhir pembelajaran di setiap siklus menunjukkan adanya peningkatan hasil belajar yaitu nilai rata-ratanya siklus I 70 dan siklus II 82. Hal ini dikarenakan dalam pembelajaran task based learning siswa dituntut aktif dalam proses pembelajaran sehingga berpengaruh pada hasil belajar siswa. Penerapantask based learning siswa tidak hanya mencoba memahami tugas yang diberikan, tetapi siswa juga harus mengetahui konsep dan mekanismenya [13]. Pembelajaran yang dikemas dengan tujuan agar dapat membangun pengetahuan siswa, yaitu melalui pembelajaran yang melibatkan siswa aktif dalam proses pembelajaran [12] .Sejalan dengan hasil penelitian [7] menunjukkan bahwa dengan menerapkan pembelajaran task based learning dapat mengembangkan keterampilan berpikir siswa. Proses pembelajarannya sendiri banyak mengajarkan siswa untuk belajar aktif serta ketersediaan sarana praktikum yang memadai, tetapi tidak terlepas dari semua itu bahwa pembelajaran dengan menggunakan metodemetode yang lain dapat pula digunakan pada pembelajaran konsep larutan bufer.

\section{KESIMPULAN}

Keterampilan Generik Sains (KGS) yang dicapai siswa pada pembelajaran bufer dengan model task based learning, pada siklus I diperoleh nilai rata-rata 70 dan siklus II 82 . Hal ini menunjukkan ada peningkatan hasil belajar. Tetapi pada indikator KGS inferensi logika baik siklus I maupun siklus II masih diperoleh nilai terendah dibandingkan dengan indikator KGS lainnya yaitu rata-rata 63.

\section{DAFTAR PUSTAKA}

Chang, R. (2005). Kimia Dasar: Konsep-konsep Inti, Jilid II (Ed. Ketiga). Terjemahan oleh Suminar Setiadi Achmadi. Jakarta: Erlangga.p.4.

McMurry, J.E. dan R.C.Fay. (2012). Chemistry (sixth edition). New York: Pearson Prentice Hall. p.1

Oxtoby, et.al. (2001). Prinsip- prinsip Kimia Modern Edisi Keempat Jilid I. Jakarta: Erlangga.p.4

Liliasari, et.al. (2007). "Scientific Concept And Generic Science Skill Relationship In The $21^{\text {th }}$ Century Science Educatios" Seminar Proceding of The First International Seminar of Science Education. Tersedia di http://file.upi.edu. p 4.

Brotosiswoyo, B.S. (2001). Hakekat Pembelajaran MIPA dan Kiat Pembelajaran Kimia di Perguruan Tinggi. Jakarta: PAU- PPAI.p.53

Warsono dan Hariyanto. (2012). Pembelajaran Aktif Teori dan Asesmen. Bandung: PT Remaja Rosdakarya.p.2.

Zhou, Q., Huang, Q., dan Tian, H. (2013). Development Students' Critical Thinking Skills by Task-Based Learning In Chemistry Experimen Teaching. Scientific Research, 4, (12A), 40-45.

Arikunto, S. (2010). Prosedur Penelitian Suatu Pendekatan Praktik. Jakarta: PT. Rineka Cipta.p.131

Putra, R.S. (2013). Desain Belajar Mengajar Kreatif Berbasis Yogyakarta:DIVAPress.p.132.

Dahar, R.W. (1996). Teori-Teori Belajar dan Pembelajaran. Jakarta: Erlangga.p.79.

Suyono dan Haryanto. (2012). Belajar dan Pembelajaran Teori dan Konsep Dasar. Bandung: PT Remaja Rosdakarya.p.105. 
[Riyanto, Y. (2010). Paradigma Baru Pembelajaran. Jakarta: Kencana Persada Media Group.p.169.

Harden, R.M., Crosby, J., Davis, M.H., Howie, P.W, dan Struthers, A.D. (2010) Task-based learning: the answer to integration and problem based learning in the clinical years. Medical Education,34:391-397. 